\title{
(C) FECAP
}

DOI: http://dx.doi.org/10.7819/rbgn.v15i46.1170

Subject Area: Finance and Economics

Value or Growth Strategy? Empirical Evidence in Brazil

Estratégia de Valor ou de Crescimento? Evidências Empiricas no Brasil

¿Estrategia de Valor o de Crecimiento? Evidencias Empiricas en Brasil

\author{
Rebeca Albuquerque Cordeiro ${ }^{1}$ \\ Márcio André Veras Machado
}

Received on December 18, 2011 / Approved on March 5, 2013

Responsible Editor: João William Grava, Doctor

Evaluation Process: Double Blind Review

\begin{abstract}
This article aimed at verifying the existence of value versus growth and at identifying the variables that best explain their impact on Brazilian stock profits. To this end, we tested book-to-market, price-earnings and price-to-cash flow variables. Two methodological approaches were employed: portfolio analysis, in which portfolios were formed according to each variable of interest; and regression analysis with panel data, based on individual assets. The sample was made up of companies with shares traded in BM\&FBovespa during the 1995-2008 period. According to results found, growth stocks presented higher profits than value stocks. Thus, we may conclude that the well-documented value versus growth is not valid in Brazil, since empirical evidence supported growth strategies. Due to the long
\end{abstract}

research period, results may signal prevalence of growth strategy in the long term. Furthermore, the high volatility of emerging countries' capital markets was emphasized, as pointed out by Fama and French (1998). Moreover, to establish investment strategies that allow for greater profits, it was found that the variable that best identifies growth stocks is the book-to-market ratio.

Keywords: Value versus growth. Stocks. Investment strategies.

\section{RESUMO}

Este artigo teve como objetivo verificar a existência do efeito valor-crescimento e identificar as variáveis que melhor explicam sua incidência nos retornos das açôes brasileiras. Para isso, foram testadas as variáveis book-to-market, lucro/preço

1. Doctor in Finance by Universidade Federal da Paraíba - UFPB. Professor at the Instituto Federal de Educaçáo, Ciência e Tecnologia da Paraíba. [rebecacordeiro1@gmail.com]

2. Doctor in Management by Universidade de Brasília - UnB. Professor of the Programa de Pós-Graduação em Administração/ PPGA at Universidade Federal da Paraíba and of the Programa Multiinstitucional e Inter-regional de Pós-Graduação em Ciências Contábeis - UnB/UFPB/UFRN. [mavmachado@hotmail.com]

Authors' address: Cidade Universitária - Castelo Branco, João Pessoa - PB Cep. 58059-900 - Brazil 
e fluxo de caixa/preço. Foram utilizadas duas abordagens metodológicas: análise de portfólio, na qual as carteiras foram formadas de acordo com cada variável de interesse; e análise de regressão com dados em painel, baseada em ativos individuais. A amostra foi composta por empresas com açôes negociadas na BM\&FBovespa, no período de 1995 a 2008. De acordo com os resultados obtidos, as açóes de crescimento apresentaram retornos superiores às açôes de valor. Com isso, pode-se concluir que o bem documentado efeito valor-crescimento não se caracteriza no Brasil, uma vez que as evidências empíricas mostraram-se favoráveis às estratégias de crescimento. Em função do longo período estudado, os resultados obtidos podem estar sinalizando o predomínio da estratégia de crescimento no longo prazo. Além disso, ressalta-se a alta volatilidade dos mercados de capitais de países emergentes, conforme destacam Fama e French (1998). Ademais, para estabelecer estratégias de investimento que possibilitem maiores retornos, verificou-se que a variável que melhor identifica as ações de crescimento é o índice book-to-market.

Palavras-chave: Efeito valor-crescimento. Ações. Estratégias de investimento.

\section{RESUMEN}

Este artículo tiene por objetivo verificar la existencia del efecto valor-crecimiento e identificar las variables que explican mejor su impacto sobre el rendimiento de las acciones brasileńas. Para ello, hemos probado las variables book-to-maket, lucro/precio y flujo de caja/precio. Se han aplicado dos enfoques metodológicos: el análisis de la cartera, carteras que se crearon de acuerdo con cada variable de interés y el análisis de regresión con datos de panel sobre la base de activos individuales. La muestra se obtuvo de empresas con acciones negociadas en BM\&FBovespa, en el período de 1995 a 2008. De acuerdo con los resultados, las acciones de crecimiento tuvieron un mayor rendimiento que las acciones de valor. Por lo tanto, podemos concluir afirmando que el bien documentado efecto valor-crecimiento no existe en Brasil, ya que la evidencia empírica mostró su apoyo a las estrategias de crecimiento. Debido a que el periodo de tiempo estudiado fue extenso, los resultados pueden indicar el dominio de la estrategia de crecimiento a largo plazo. Por otra parte, destaca la alta volatilidad de los mercados de capitales en los países emergentes, como destacan Fama y French (1998). Además, para establecer estrategias de inversión que permitan una mayor rentabilidad, se deduce que la variable que mejor identifica las acciones de crecimiento es el índice book-to-market.

Palabras clave: Efecto valor-crecimiento. Acciones. Estrategias de inversión.

\section{INTRODUCTION}

Evidence that value investment strategies outperform growth strategies has been intensely discussed. The difference between profits from value and growth stocks is called value premium. Rating of both these kinds of stocks is established according to fundamental variables, such as the book-to-market $(\mathrm{B} / \mathrm{M})$, the earnings/price $(\mathrm{E} / \mathrm{P})$ and the cashflow/price $(\mathrm{CF} / \mathrm{P})$ ratios, amongst others. Because these variables refer both to companies' book and market equities, future prospects can be identified from their internal context as well as from investors' points of view.

Fama and French (1998) point out that companies with high $\mathrm{B} / \mathrm{M}, \mathrm{E} / \mathrm{P}$ and $\mathrm{CF} / \mathrm{P}$ (value) indexes tend to get lower profits, whilst those with low $\mathrm{B} / \mathrm{M}, \mathrm{E} / \mathrm{P}$ and $\mathrm{CF} / \mathrm{P}$ (growth) indexes present consistently higher profits. In a way, this highlights controversy regarding value versus growth, stating that profits from value companies are greater than those from growth companies. All this raises a lot of discussion and countless different interpretations.

Basically, two different approaches try to justify the existence of the value premium. Fama and French $(1993,1995)$ argue that value strategies outperform growth strategies because they are riskier. Thus, investors in value stocks are rewarded for taking higher risks. On the other hand, the behavioral approach (LAKONISHOK; 
SHLEIFER; VISHNY, 1994; HAUGEN, 1995; LA PORTA et al., 1997) suggests that value strategies produce higher profits due to investors' irrationality. Accordingly, by overestimating companies' performances in the past, investors overvalue growth stocks and underestimate value stocks, justifying the greater future profits of the former over the latter.

Apart from different perspectives regarding value versus growth, several variables have been tested in order to explain variations in the average profit of stocks. Considering the two factors proposed by Fama and French (1992), certain studies use firm size (VM) and $\mathrm{B} / \mathrm{M}$ as proxies for value versus growth (CHAN; HAMAO; LAKONISHOK, 1991; FAMA; FRENCH, 1998). Additionally, other specific company variables are suggested, such as $\mathrm{E} / \mathrm{P}$ and $\mathrm{CF} / \mathrm{P}$ (LAKONISHOK; SHLEIFER; VISHNY, 1994), price/sales (P/S) and debt/equity (D/E) (BARBEE; MUKHERJI; RAINES, 1996; LELEDAKIS; DAVIDSON, 2001), dividend yield (D/P) (FAMA; FRENCH, 1998) and liquidity (ATHANASSAKOS, 2009).

In order to avoid possible data snooping, a lot of research on value versus growth has been carried out outside the United States. Capaul, Rowley and Sharpe (1993), researching six countries in the 1981-1992 period, argue that the value premium is consistent amongst international stock profits. Considering a longer period, Fama and French (1998) researched the world's 13 main markets and 16 emerging countries in the 19751995 period. There are also papers that study the value premium in specific countries such as Japan (CHAN; HAMAO; LAKONISHOK, 1991; CAI, 1997), Australia (GHARGHORI; STRYJKOWSKI; VEERARAGHAVAN, 2012) and Canada (ATHANASSAKOS, 2009).

Fama and French (1998) found that the value premium does exist in emerging markets. The authors point out, however, that these markets are highly volatile and show little correlation with excess profits. Capaul, Rowley and Sharpe (1993) warn that the lack of a theory to explain the better performance of value stocks makes it impossible to predict whether this phenomenon will continue, be reduced or disappear completely in the future.

Accordingly, this paper intends to verify the existence of value versus growth and identify the variables that best explain its impact on stock profits in Brazil. We hope to contribute to developing this field of research, mainly because of the paper's methodological approach and because it encompasses a larger period than that of previous research published in Brazil. Moreover, we hope to help investors select investment strategies, since we provide insights to identify value and growth companies in Brazil.

The paper is organized as follows: the section below provides a quick review of literature on the subject, at national and international levels. Next are presented the study's methodological procedures, results, conclusion and, last but not least, references.

\section{LITERATURE REVIEW}

The Efficient Market Hypothesis, a basic concept in the development of Modern Finance Theory, refers to the way relevant information becomes incorporated into asset prices. According to Fama (1970), markets are considered efficient whenever agents quickly assimilate available information, never allowing for abnormal company asset profits that result from this information. A balanced market's assumptions are sufficient conditions for the Efficient Market theory. Thus, it has been controversial amongst researchers who analyze the asset pricing process (COPELAND; WESTON; SHASTRI, 2005; LO, 2007).

The efficient market hypothesis can only be tested by an asset pricing model. The Capital Asset Pricing Model (CAPM) was developed by Sharpe (1964), Lintner (1965) and Black (1972). According to this model, the required profit rate for any risky asset is a result of three variables: beta, which measures assets' sensitivity to market portfolios; the rate of profits on risk-free assets; and a risk premium, resulting from the difference between market portfolios' expected profits and risk-free rates. 
The CAPM is a single factor model that proposes a positive and linear relationship between a beta title and its expected profits. Given that the market portfolio is efficient in terms of average and variance, any differences in stocks' expected profits can be fully explained by differences in beta - that is, other variables add nothing in terms of explaining expected profits (FAMA; FRENCH, 2004). The assumption that stock profits refer only to beta and that no other variables possess any additional explanatory power has been challenged, however, since the 1970s.

The work of Black, Jensen and Scholes (1973) aimed at carrying out additional tests to CAPM that were capable of avoiding some of the previous studies' problems, which they believe occurred due to incompatibility between the estimation method employed and the structure of the stock profit generating process. By relaxing the assumption that investors can borrow or lend unlimited amounts at a risk free rate, the authors formulate a model that suggests the existence of a second factor in establishing profits, the "beta factor", which corresponds to the expected profit of a portfolio whose covariance with market profits is zero. The authors reveal that this model is best suited to the nature of the data structure and believe that there are economic assumptions that are compatible with this second factor that also are consistent with the balanced capital market.

An alternative to the CAPM is the Arbitrage Pricing Theory (APT) developed by Ross (1976). This theory assumes that profits on securities are produced by a number of general and sector market factors - that is, that the systematic risk is due to other economic factors, not just to beta. In this sense, one of APT's main advantages is its ability to handle a variety of factors, which may make it more representative of reality (ROSS, 1976).

From then on, several studies have been carried out so as to test multifactor models capable of improving the explanatory power of stock profits, even in cases where CAPM beta was statistically significant. The main argument was that these factors reflect underlying economic aspects, which produce systematic risk in profits not captured by CAPM beta (FAMA; FRENCH, 1993). Fama and French (1993) revealed that stock prices with high $\mathrm{B} / \mathrm{M}$ rates and low market value tend to present joint increase and decrease movements, suggesting that a common risk factor exists.

Lakonishok, Shleifer and Vishny (1994), on the other hand, do not deny the possibility that there are pricing factors associated with value and growth stocks, but present an alternative argument based on evidence that the value premium associated with Fama and French (1993) portfolios is simply too high, and its covariance with macroeconomic factors too low (and in some cases negative) to be considered compensation for systematic risk. In short, theoretical discussion focuses on the possibility of these factors in fact representing an economically relevant aggregate risk (DANIEL; TITMAN, 1997).

In this context, two perspectives of analysis substantiate research on value versus growth: the first based on Fama and French's argument (1993, $1995,1996)$ that value strategies present higher profits than growth strategies to compensate their higher risk level; and the second based on Lakonishok, Shleifer and Vishny's argument (1994) that value stocks present higher realized profits due to investors being too optimistic about past expectations that growth stocks' good performances will occur in the future. Thus, growth stocks (also called "glamour stocks") end up luring gullible investors that raise their prices due to high demand and consequently reduce their real profits.

\section{I Value versus growth}

For decades, investment scholars and professionals have argued that value strategies outperform the market. Their basic premise is to invest in stocks that are traded below their real value. Companies with below average prospects are classified as value companies; and 
companies with strong performances in the past - and expected good performances in the future - are classified as growth companies. Value companies are characterized by high rates of price fundamentals (profits, dividends, cashflow and book-to-market ratio), whereas growth companies present low rates (GHARGHORI; STRYJKOWSKI; VEERARAGHAVAN, 2012). Figure 1 summarizes the main empirical evidence on value versus growth, internationally.

\begin{tabular}{|c|c|c|c|}
\hline $\begin{array}{l}\text { Empirical } \\
\text { evidence }\end{array}$ & Period & Variables tested & Methodology \\
\hline $\begin{array}{l}\text { Chan, Hamao and Lakonishok } \\
\text { (1991) }\end{array}$ & $1971-1988$ & $\begin{array}{l}\mathrm{B} / \mathrm{M} \text {, firm size, } \mathrm{E} / \mathrm{P} \text { and } \\
\mathrm{CF} / \mathrm{P}\end{array}$ & $\begin{array}{l}\text { Portfolio analysis and } \\
\text { regression analysis }\end{array}$ \\
\hline Fama and French $(1992,1993)$ & $1962-1989$ & $\begin{array}{l}\mathrm{B} / \mathrm{M} \text {, firm size, } \mathrm{E} / \mathrm{P} \text { and } \\
\text { leverage }\end{array}$ & $\begin{array}{l}\text { Portfolio analysis and } \\
\text { regression analysis }\end{array}$ \\
\hline $\begin{array}{l}\text { Capaul, Rowley and Sharpe } \\
\text { (1993) }\end{array}$ & $1981-1992$ & Price/Book Equity & $\begin{array}{l}\text { Portfolio analysis and } \\
\text { regression analysis }\end{array}$ \\
\hline $\begin{array}{l}\text { Lakonishok, Shleifer and Vishny } \\
\text { (1994) }\end{array}$ & $1963-1990$ & $\mathrm{E} / \mathrm{P}$ and $\mathrm{CF} / \mathrm{P}$ & $\begin{array}{l}\text { Portfolio analysis and } \\
\text { regression analysis }\end{array}$ \\
\hline $\begin{array}{l}\text { Barbee, Mukherji and Raines } \\
\text { (1996) }\end{array}$ & $1979-1991$ & $\mathrm{P} / \mathrm{S}$ and $\mathrm{D} / \mathrm{CP}$ & $\begin{array}{l}\text { Portfolio analysis and } \\
\text { regression analysis }\end{array}$ \\
\hline Daniel and Titman (1997) & $1962-1989$ & $\mathrm{~B} / \mathrm{M}$, firm size & $\begin{array}{l}\text { Portfolio analysis and } \\
\text { regression analysis }\end{array}$ \\
\hline Cai (1997) & $1977-1991$ & $\begin{array}{l}\mathrm{B} / \mathrm{M} \text {, firm size, } \mathrm{E} / \mathrm{P} \text { and } \\
\mathrm{CF} / \mathrm{P}\end{array}$ & Portfolio analysis \\
\hline Fama and French (1998) & $1975-1995$ & $\mathrm{~B} / \mathrm{M}, \mathrm{E} / \mathrm{P}, \mathrm{CF} / \mathrm{P}, \mathrm{D} / \mathrm{P}$ & $\begin{array}{l}\text { Portfolio analysis and } \\
\text { regression analysis }\end{array}$ \\
\hline $\begin{array}{l}\text { Gharghori, Stryjkowski and } \\
\text { Veeraraghavan (2012) }\end{array}$ & $1993-2004$ & $\begin{array}{l}\mathrm{B} / \mathrm{M} \text {, firm size, } \mathrm{E} / \mathrm{P}, \mathrm{P} / \mathrm{S} \text {, } \\
\mathrm{CF} / \mathrm{P} \text { and leverage }\end{array}$ & $\begin{array}{l}\text { Portfolio analysis and } \\
\text { regression analysis }\end{array}$ \\
\hline Athanassakos (2009) & $1985-2005$ & $\begin{array}{l}\mathrm{B} / \mathrm{M}, \mathrm{E} / \mathrm{P} \text {, firm size and } \\
\text { liquidity }\end{array}$ & Portfolio analysis \\
\hline Zhang (2009) & $1966-2005$ & B/M, firm size & Main components' analysis \\
\hline
\end{tabular}

Chart 1 - International research on value versus growth.

Source: the authors.

Value versus growth was first observed in Japan by Chan, Hamao and Lakonishok (1991). They studied the differences in the profits of Japanese stocks as to the underlying behavior of four variables: E/P, firm size, $\mathrm{B} / \mathrm{M}$ and $\mathrm{CF} / \mathrm{P}$. Their results reveal a significant relationship between these variables and expected profits in the Japanese market. Among the four considered variables, however, $\mathrm{B} / \mathrm{M}$ and $\mathrm{CF} / \mathrm{P}$ have the most relevant positive impact on expected profits. The authors also included stocks with negative profits in their research, and registered that they produce fundamentally higher profits.

Fama and French $(1992,1993)$ question the CAPM by presenting empirical evidence that beta's capacity to explain average stock profits is small or null. Instead, they suggest and test other variables that may be more appropriate: firm size, $\mathrm{B} / \mathrm{M}, \mathrm{E} / \mathrm{P}$ and financial leverage. As mentioned earlier, Fama and French $(1995,1996)$ suggest 
a rational explanation for value versus growth, claiming that value strategies present higher profits than growth strategies so as to compensate for their higher risk level.

Years later (FAMA; FRENCH, 2006), the authors carried out research to verify how the value premium varies according to the size of the company, considering Loughran's (1997) evidence that there is no value premium in value stocks from high market value US companies after 1963. In the first sub-period analyzed (1926-1963), the value premium was virtually identical for companies with high and low market values. In the second sub-period (1963-2004), a strong value premium was also identified, with few differences between stocks from companies with high and low market values. This result was confirmed by a sample of data from 14 countries over the 1975-2004 period. In this way, Fama and French (2006) suggest that the weak relationship between $\mathrm{B} / \mathrm{M}$ rates and high market value stock profits, registered by Loughran (1997), can be a "random aberration", probably due to scarce value stocks (with high $\mathrm{B} / \mathrm{M}$ rates) and high market value.

In contrast, Lakonishok, Shleifer and Vishny (1994) found little or no evidence that value strategies are in fact riskier. They used variables $\mathrm{E} / \mathrm{P}$ and $\mathrm{CF} / \mathrm{P}$ when trying to explain the variation of US stock profits. Subscribers of a behavioral approach, the authors argue that value strategies produce greater profits because of errors in investors' expectations regarding the future performance of stocks.

From the same perspective, Daniel and Titman (1997) carried out research in the US market to verify whether there are in fact company characteristics directly associated with firm size and $\mathrm{B} / \mathrm{M}$; and if there is a risk premium associated with these factors. In other words, they sought to test whether the high profits of companies of low market value and high B/M rates could be attributed to factor loading. Thus, they proposed a "Characteristic-based Pricing Model". Their results reveal that there is no risk factor associated with company characteristics, nor a premium value associated with any of one of Fama and French's (1993) three factors. To the authors, this evidence suggests that value stocks' high profits cannot be explained as compensation for the risk taken by investors when investing in this type of asset, but rather by characteristics that are usual in this kind of company: same line of business, same industry or same region (DANIEL; TITMAN, 1997).

Cai (1997) also evaluated the performance of growth and value strategies, in order to reconcile Fama and French's (1993, 1995, 1996) and Lakonishok, Shleifer and Vishny's (1994) conflicting results and prove which of these two arguments is more appropriate to explaining value versus growth. Based on data from the Japanese market in the 1977-1991 period, the author found that, through various strategies, value stocks outperform growth stocks for five years following portfolio formation. Growth portfolios are made up of growth stocks that presented steady growth as to earnings and cashflow, and whose investors expected this strong performance to continue in the future. They did not meet market expectations, however, whereas value stocks surprised investors with better performances. Accordingly, this evidence from the Japanese market is consistent with Lakonishok, Shleifer and Vishny's argument (1994).

Capaul, Rowley and Sharpe (1993) carried out research in six countries (France, Germany, Switzerland, UK, USA and Japan) in the 1981-1992 period, demonstrating that the value premium is consistent across the six main international markets (at that time). The authors do not make any statements as to the phenomenon's continuity, given the lack of theoretical consensus to explain its existence. Due to the phenomenon's global nature, they do recommend, however, that investors pay attention to their stances concerning these two types of assets, in the future.

Fama and French (1998) also carried out international research in which they analyzed 
value versus growth in 13 of the world's main international markets and in 16 emerging countries over the 1975-1995 period. Using several variables $(\mathrm{B} / \mathrm{M}, \mathrm{E} / \mathrm{P}, \mathrm{CF} / \mathrm{P}$ and $\mathrm{D} / \mathrm{P})$, they found that value versus growth is a global phenomenon. To the authors, this evidence confirms their earlier argument that value stocks' premium is in fact real.

Barbee, Mukherji and Raines (1996) suggest that two other variables are more appropriate than $\mathrm{B} / \mathrm{M}$ when assessing specific companies: the price/sales (P/S) and the debt/ equity (D/E) ratios. They argue that, unlike $\mathrm{B} / \mathrm{M}$, these variables suffer little influence from depreciation and inventory accounting methods.

Gharghori, Stryjkowski and Veeraraghavan (2012) tested the existence of value versus growth and the variable that best characterizes their impact in the Australian market. Using data from January 1993 to December 2009, the authors confirmed the phenomenon's existence in that specific market. All variables employed $(B / M$, $\mathrm{E} / \mathrm{P}, \mathrm{CF} / \mathrm{P}$ and $\mathrm{P} / \mathrm{S}$ ) were statistically significant; in multivariate regressions, however, the $\mathrm{B} / \mathrm{M}$ ratio proved to be the best proxy. The authors also divided the sample into companies that presented negative and positive results (profits and cashflows) and, within these two subgroups, the best proxies for value versus growth were the $\mathrm{B} / \mathrm{M}$ and $\mathrm{CF} / \mathrm{P}$ ratios, respectively .

Athanassakos (2009) analyzed the existence of value versus growth in Canada from 1985 to 2005. The author found a strong occurrence of the phenomenon over the analyzed period, persisting in periods of market rising and falling as well as in recessions and recoveries. The author points out that Canada's value premium can be compared to USA's, suggesting that, despite differences between these two markets, the structure of the Canadian market had no differential effect on the value premium.

Finally, Zhang's research (2009) analyzed Fama and French's (1993, 1996) and Daniel and Titman's (1997) conflicting evidence. The author used the principal components method to build compound factors for individual assets and portfolios. The results reveal that main components analysis of individual assets did not successfully explain firm size and B/M effects. In contrast, he found that portfolio analysis was better than Fama and French's factors (factor loadings were clearly connected to firm size and $\mathrm{B} / \mathrm{M}$ ratios), and also passed the test of the model introduced by Daniel and Titman (1997). The author's main conclusion is that the effects of firm size and $\mathrm{B} / \mathrm{M}$ are consistent with the rational asset pricing theory, although underlying systematic factors are no more important than accounting as to profit variation.

All this having been said, we can observe that, despite not having reached any consensus as to its causes, traditional value versus growth can be classified as an international phenomenon. It is important, however, to point out the existence of characteristics that are specific to emerging markets and which may affect its characterization, such as high volatility and small correlation with excess profits (FAMA; FRENCH, 1998). Next, we present main empirical evidence from the Brazilian market, also summarized in Figure 2. Generally, these studies show different results regarding variables tested and their power to explain value versus growth.

The work of Mellone Jr. (1999) found that variables $\mathrm{B} / \mathrm{M}$ and $\mathrm{E} / \mathrm{P}$ are strongly capable of explaining profits and that variables firm size and leverage are apparently irrelevant. In contrast, the results of Costa Jr. and Neves (2000) suggest that the most noteworthy fundamental variables are firm size and $\mathrm{B} / \mathrm{M}$, and that, although the $\mathrm{E} / \mathrm{P}$ ratio is significant, it presents less explanatory power than the other variables.

Rodrigues' two-factor models (2000) lead to results that are similar to Fama and French's (1992), indicating the relevance of B/M's and firm size's contribution in the explanation of stock profits. However, the degree of these variables' significance reveals itself rather contradictory when comparing portfolios made up of value and growth stocks. The work of Rostagno, Soares and 
Soares (2006) indicates that portfolios sorted by $\mathrm{E} / \mathrm{P}$ and Ebitda ratios are the value strategies with the greatest profit. The importance of the E/P ratio is also verified by Saito, Savoia and Sousa (2009), with shares from the Brazilian electricity sector.

\begin{tabular}{|c|c|c|c|}
\hline $\begin{array}{l}\text { Empirical } \\
\text { evidence }\end{array}$ & Period & Variables tested & Methodology \\
\hline $\begin{array}{l}\text { Mescolin, Braga and Costa Jr. } \\
\text { (1997) }\end{array}$ & $1986-1996$ & $\mathrm{~B} / \mathrm{M}, \mathrm{E} / \mathrm{P}, \mathrm{D} / \mathrm{P}$ & Statistical evidence was not tested \\
\hline Mellone Jr. (1999) & $1994-1998$ & $\begin{array}{l}\text { Beta, firm size, } B / M \text {, } \\
\text { leverage and } E / P\end{array}$ & $\begin{array}{l}\text { Portfolio analysis and regression } \\
\text { analysis }\end{array}$ \\
\hline $\begin{array}{l}\text { Ramos, Picanço and Costa Jr. } \\
\text { (2000) }\end{array}$ & $1989-1994$ & Beta, B/M & Portfolio analysis \\
\hline Costa Jr. and Neves (2000) & $1986-1996$ & Beta, firm size, $B / M, E / P$ & Regression analysis \\
\hline Rodrigues (2000) & $1991-1999$ & Beta, B/M, firm size & $\begin{array}{l}\text { Portfolio analysis and regression } \\
\text { analysis }\end{array}$ \\
\hline Braga and Leal (2002) & $1991-1998$ & $\mathrm{~B} / \mathrm{M}$, firm size & Portfolio analysis \\
\hline $\begin{array}{l}\text { Rostagno, Soares and Soares } \\
\text { (2005) }\end{array}$ & $1995-2001$ & $\mathrm{~B} / \mathrm{M}, \mathrm{E} / \mathrm{P}, \mathrm{D} / \mathrm{P}, \mathrm{P} / \mathrm{S}$ & Portfolio analysis \\
\hline Pedreira (2005) & $2001-2004$ & $\mathrm{~B} / \mathrm{M}$ & Portfolio analysis \\
\hline $\begin{array}{l}\text { Rostagno, Soares and Soares } \\
\text { (2006) }\end{array}$ & $1994-2003$ & $\begin{array}{l}\text { B/M, E/P, D/P, P/S, } \\
\text { EBITDA/P, liquidity }\end{array}$ & Portfolio analysis \\
\hline $\begin{array}{l}\text { Fregnani, Faneco and Famá } \\
\text { (2008) }\end{array}$ & $1995-2005$ & Beta, B/M & Portfolio analysis \\
\hline Saito, Savoia and Sousa (2009) & $1997-2007$ & $\mathrm{E} / \mathrm{P}$ & Portfolio analysis \\
\hline
\end{tabular}

Chart 2 - Brazilian research on value versus growth.

Source: the authors.

Some of these studies also intend to verify the existence of the so-called "golden opportunity", suggested by Haugen (1995), within the Brazilian market. There is plenty of international evidence that, although value stocks produce higher profits, they present a lower level of risk than growth stocks. This fact goes completely against what Modern Financial Theory states: that risk and profit are directly related variables. Accordingly, Haugen (1995) proposes that this is a "golden opportunity" available to investors who want to receive high, non-risky profits in the long term.

Although Ramos, Picanço and Costa Jr. (2000), Fregnani, Faneco and Famá (2008) and Saito, Savoia and Sousa (2009) have found evidence of the "golden opportunity" in Brazil, their results have no statistical significance. Rostagno, Soares and Soares (2005) report that their portfolios made up by E/P ratios seems to confirm the existence of this premium, but their explanation is not risk-based - it is based on the smaller liquidity of stocks. Risk measures used by Rodrigues (2000) prove to be superior for value stock portfolios, contradicting the existence of the "golden opportunity" within the Brazilian market.

Regarding the existence of value versus growth itself, virtually all Brazilian research confirms that value stocks outperform growth 
stocks in terms of profit. However, there is some evidence in favor of growth strategies.

Mescolin, Braga and Costa Jr. (1997) analyzed Brazilian stocks between 1986 and 1996. They reveal that, in 1990 and 1991, the performance of growth stocks was better than that of value stocks. From 1992 on, the situation reversed, and value stocks began to present better profits. In the last year of research (1996), however, they once again presented an unfavorable result.

In a study of stocks that make up the IBrX 50 Index, Pedreira (2005) found that, in 2001 and 2002, the portfolio made up of value stocks presented a smaller average annual profit than that obtained by growth stocks. The author suggests that this fact may be connected to the macroeconomic conditions of the sectors of activity of companies in the index during that period.

Ramos, Picanço and Costa Jr. (2000) studied the behavior of stocks traded in BM\& FBovespa between 1988 and 1994, and present results that favor growth stocks in 1988, 1989 and 1994. Building on the work of these authors, Fregnani, Faneco and Famá (2008) carried out similar research for the 1995-2005 period. Growth stocks performed better in the years 1999, 2000, 2002 and 2003. This evidence is confirmed by Saito, Savoia and Sousa (2009), whose results favor growth stocks in 1999, 2000, 2002, 2003 , 2006 and 2007, considering annual profits, and from 2001 to 2003, regarding cumulative profitability.

All this having been said, this paper intends to confirm the existence of value versus growth in Brazil, considering subtle evidence in favor of growth strategies. Moreover, as shown in the next section, we will use two methodological approaches in order to identify which variables best explain stocks' average profits.

\section{METHODOLOGY}

In this section, we present the methodological procedures used to achieve the previously established goals, based on the work of Gharghori, Stryjkowski and Veeraraghavan (2012).

\section{I Research characterization}

This research is classified as empiricalanalytic. According to Sánchez Gamboa (1987), this approach is based on principles that are valid for natural and physical sciences, and emphasizes causal relationships between variables, systematization of empirical data and control by means of statistical analysis. From this perspective, scientific validity results from testing instruments used for collecting and processing data and from the degree of statistical significance.

\subsection{Data}

The researched population was made up of all companies with stocks listed in the State of São Paulo Stock Exchange - BM\&FBovespa (Bolsa de Valores do Estado de São Paulo BM\&FBovespa), between June 1, 1995 and June 30,2008 . This period was used because it included an economically stable phase, after July 1994 and before the global financial crisis (2008-2009). All data was collected in the Economática database.

We used four filters to ensure the accuracy of accounting data. Thus, financial companies were excluded from the sample, because, according to Fama and French (1992), their high indebtedness can distort the book-to-market ratio, and it does not mean the same as non-financial companies' high indebtedness. We also excluded companies that did not submit monthly rates during 12 consecutive months after portfolio formation, market value on December 31 and June 30 of each year, or Net Worth on December 31 of each year.

\subsection{Methods}

In order to analyze the relationship between fundamental variables and the average profits of stocks, two methods were used, namely: 
portfolio analysis, in which portfolios were formed according to each variable of interest and the relationship with average profits was investigated; and panel data regressions based on individual assets.

\subsection{Portfolio analysis}

The first phase of analysis aimed at verifying whether value versus growth does exist in the Brazilian stock market. To this end, we used the portfolio analysis method used by Fama and French (1993) in drafting the Three-Factor Model. The use of this procedure is justified by the need to reduce possible "noise" or "measurement errors" pointed out by Blume (1975). According to this author, when using sample data to draw conclusions about a certain population, sample values correspond to the population's values with added random noise -significant to individual assets, but not to portfolios made up of various assets. Thus, portfolio profits provide a more efficient estimate of expected profits, since they tend to be less affected by fluctuations in individual assets.

Accordingly, five stock portfolios were made up each year, based on each of the five variables selected for the study. Sample stocks were sorted decreasingly, in the month of June of each $t$ year, beginning in 1995 and ending in 2008. Quintile 1 (Q1) represents companies with the highest value variable (value stocks), whereas Quintile 5 (Q5) is made up of companies with the lowest value variable (growth stocks). Weighted average profit for each quintile was calculated from July of year $t$ to June of year $t+1$. Portfolios were annually rebalanced. To calculate excess profit, we used the Selic rate as a proxy for riskfree profit (FRALETTI, 2004).

Each year, we analyzed data referring to 149 stocks $(25,65 \%$ of the population), on average, presenting, in 2003, a minimum 103 analyzed stocks $(16,89 \%$ of the population) and, in 2006, a maximum 191 (33,81\% of the population). Portfolio analysis is capable of identifying relationships between variables and portfolios' subsequent profits. We concluded that value versus growth does exist, if premium value can be proven - that is, if there is a significant difference between the profits of value (Q1) and growth (Q5) portfolios.

\subsubsection{Regression analysis}

The second phase of analysis aimed at investigating the explanatory power - individually and as a whole - of the five studied variables when explaining Brazilian stock profits. To this end, we carried out univariate and multivariate regressions using individual assets. Although Gharghori, Stryjkowski and Veeraraghavan (2012) used pooled regressions, we considered using panel data regressions more appropriate to this research.

Panel data allows for the econometric analysis of basic units arranged in transverse sections, over time (WOOLDRIDGE, 2002). The main advantage of this technique is that it allows dynamic relationships to be observed and heterogeneity to be controlled neither of which are possible when using only cross-sectional data (ARELLANO; BOVER, 1990). We must emphasize that the basic unit of this research is made up of companies that have stocks listed in BM\&FBovespa, observed at different moments. In this way, we consider this estimation method the most appropriate, since it takes the heterogeneity of sample companies' stocks into account.

The set of variables in this research is made up of stock profits, as the dependent variable, and the following explanatory variables: $\mathrm{B} / \mathrm{M}$, $\mathrm{CF} / \mathrm{P}$ and $\mathrm{E} / \mathrm{P}$ ratios, as proxies for value versus growth; and financial leverage and firm size as control variables, because of their documented associations with stock profits. Although there is no consensus in previous literature about the choice of companies' fundamental variables, proxies used in this research to test value versus growth were also successfully used by Chan, Hamao and Lakonishok (1990), Lakonishok, 
Shleifer and Vishny (1994), Cai (1997) and Gharghori, Stryjkowski and Veeraraghavan (2012).

Explanatory variables were measured on an annual basis and are defined as follows:

- Book-to-market ratio (B/M): Net Worth book value divided by company market value as of December 31 of year $t-1$;

- Cashflow/price ratio (CF/P): earnings before interest, taxes, depreciation and amortization (EBITDA) divided by stock price as of December 31 of year $t-1$;

- Earnings/price ratio (E/P): net income divided by stock price as of December 31 of year $t-1$;

- Firm size (VM): Net Worth market value as of June 30 of year $t$;

- Financial Leverage (PO/AT): value of onerous liabilities divided by company's total assets as of December 31 of year $t-1$.

Variables' capacity to explain stock profits is measured by coefficient significance. To this end, different variations were estimated from the regression model, according to Gharghori, Stryjkowski and Veeraraghavan (2012):

$$
R_{i}=\gamma_{0}+\gamma_{1} \ln \left(\frac{B}{M}\right)+\gamma_{2} \ln \left(\frac{L}{P}\right)+\gamma_{3} \ln \left(\frac{F C}{P}\right)+\gamma_{4} \ln (V M)+\gamma_{5} \ln \left(\frac{P O}{A T}\right)+\varepsilon_{i}
$$

The work of Gharghori, Stryjkowski and Veeraraghavan (2012) included many (approximately 50\%) Australian companies with negative earnings or cashflows. Thus, they treated the positive and negative values of $\mathrm{E} / \mathrm{P}$ and $\mathrm{CF} / \mathrm{P}$ variables separately. According to the authors, the value-growth concept applied to companies with positive ratios can also be applied to companies with negative ratios. In this context, companies with the most negative $\mathrm{E} / \mathrm{P}$ or $\mathrm{CF} / \mathrm{P}$ values are undervalued and present greater risk; they are also the most valuable. On the other hand, companies whose ratios are less negative are also less valuable.

In this paper there are not many companies with negative results for these two variables. Considering the annual observations of the $\mathrm{E} / \mathrm{P}$ ratio, 1,217 were positive and 274 were negative. For the CF/P ratio, we found 109 positive observations and 952 negative ones. Virtually all Brazilian studies disregard companies with negative results, except for Costa Jr. and Neves' (2000). Given Chan, Hamao and Lakonishok's (1991) and Gharghori, Stryjkowski and Veeraraghavan's (2012) arguments that companies with negative earnings produce higher profits, we created a dummy variable in this research to capture this effect.

Taking into account the estimation of regression models using panel data, we prepared a balanced panel, so that each studied company faced the same number of time observations. Thus, we included in the sample stocks that presented all the valid observations of variables focused on by this research (profit, B/M, E/P, CF/P, firm size and leverage), during the entire period of analysis (13 years). Thus, the final sample was made up of 52 shares $(9,3 \%$ of the population, on average). The next section presents the results reached following empirical analysis.

\section{RESULTS}

This section presents empirical results from the two phases of research: portfolio analysis and regression analysis. In order to provide exploratory data analysis, we first of all present variables' descriptive statistics and correlation matrix. 


\section{I Descriptive statistics}

Table 1 presents descriptive statistics of the five fundamental variables studied. All firm size variable observations were valid, thus representing the total number of annual observations in this research. Other variables also presented high rates of valid observations, contributing to a reasonable amount of data. Next, we present the average and standard deviation of variables as well as their maximum and minimum values.

Table 1 - Descriptive statistics of fundamental variables

\begin{tabular}{l|c|c|c|c|c}
\hline & B/M & E/P & CF/P & VM & PO/AT \\
\cline { 1 - 5 } Annual & 1488 & 1491 & 1061 & 1493 & 1209 \\
\cline { 1 - 5 } valid observations & 1.810 & -0.050 & 0.270 & 5895943.877 & 62.530 \\
\cline { 1 - 5 } Average deviation & 2.464 & 0.943 & 0.725 & 24196080.308 & 91.990 \\
\hline Standard deviation & 0.000 & -10.000 & -9.000 & 705.000 & 0.000 \\
\hline Minimum & 42.000 & 3.000 & 10.000 & 429922948.000 & 920.000 \\
\hline
\end{tabular}

Source: the authors.

The average book-to-market ratio was relatively low when compared to its maximum value. According to Fama and French (1993), low $\mathrm{B} / \mathrm{M}$ rates indicate growth opportunities. The same trend can be observed in the average values of $\mathrm{E} / \mathrm{P}$ and $\mathrm{CF} / \mathrm{P}$ ratios, revealing the predominance of growth companies in the Brazilian market. Cupertino and Coelho (2006) observed a decreasing $\mathrm{B} / \mathrm{M}$ ratio trend in Brazil in the
1998-2004 period - which, according to them, proves greater coherence with what is predicted by the theory of accounting conservatism. Additionally, the sample varied widely in terms of firm size, as well as of financial leverage.

In order to investigate the relationship between the five variables in this research, we created a correlation matrix which is presented in Table 2.

Table 2 - Correlation matrix for transformed variables.

\begin{tabular}{l|c|c|c|c|c}
\hline & B/M & E/P & CF/P & VM & PO/AT \\
\hline $\mathrm{B} / \mathrm{M}$ & 1.000 & & & & \\
\hline $\mathrm{E} / \mathrm{P}$ & -0.290 & 1.000 & & & \\
\hline $\mathrm{CF} / \mathrm{P}$ & 0.0542 & 0.292 & 1.000 & & \\
\hline $\mathrm{VM}$ & -0.108 & 0.042 & -0.031 & 1.000 & \\
\hline PO/AT & -0.036493 & -0.221343 & -0.009 & -0.046 & 1.000 \\
\hline
\end{tabular}

Source: the authors.

As shown in Table 2, research variables reveal no significant correlations between each other. This result confirms the findings of Cupertino and Coelho (2006), who registered low correlation levels between $\mathrm{B} / \mathrm{M}$ and variables leverage, liquidity, firm size, risk, and intangible assets. Complementing what these authors stated, here there is a slight negative 0,29 correlation between $\mathrm{E} / \mathrm{P}$ and $\mathrm{B} / \mathrm{M}$ and an insignificant correlation between $\mathrm{B} / \mathrm{M}$ and $\mathrm{CF} / \mathrm{P}$. This having been said, we believe that regression analysis will not present multicollinearity problems. 


\subsection{Portfolio analysis}

Portfolio analysis results are presented in Table 3, which contains average monthly profits in the June/1995 to June/2008 period for the five portfolios, based on book-to-market $(\mathrm{B} / \mathrm{M})$, earnings/price $(\mathrm{E} / \mathrm{P})$, cashflow/price $(\mathrm{CF} / \mathrm{P})$, firm size $(\mathrm{VM})$ and financial leverage (PO/AT) variables.

The first part of Table 3 presents portfolios' classification results for variable B/M. A strong negative relationship between $\mathrm{B} / \mathrm{M}$ and profits can be observed. Average profits decrease almost monotonically from 3,78\% in the lowest Quintile (Q5) to $1,10 \%$ in the highest Quintile (Q1), producing a 2,68\% premium (Q1-Q5). This result contradicts theory, which predicts that stocks that have higher $\mathrm{B} / \mathrm{M}$ ratios (value) produce greater profits than stocks that have lower $\mathrm{B} / \mathrm{M}$ ratios (growth).

Table 3 - Profits from portfolios based on fundamental values.

\begin{tabular}{|c|c|c|c|c|c|c|}
\hline Variables/Portfolio & 1 (Value) & 2 & 3 & 4 & 5 (Growth) & $5-1$ \\
\hline \multicolumn{7}{|l|}{ Profits (\%) } \\
\hline \multicolumn{7}{|l|}{$\mathbf{B} / \mathbf{M}$} \\
\hline Average profit & $1.10 \%$ & $2.26 \%$ & $2.24 \%$ & $3.00 \%$ & $3.78 \%$ & $2.68 \%$ \\
\hline Standard deviation & $18.03 \%$ & $17.12 \%$ & $16.17 \%$ & $16.13 \%$ & $15.43 \%$ & $11.42 \%$ \\
\hline Test $t$ & 0.7310 & 1.5858 & 1.6599 & 2.2288 & 2.9387 & 2.8166 \\
\hline p value & 0.4648 & 0.1128 & 0.0969 & 0.0258 & 0.0033 & $0.0049^{*}$ \\
\hline \multicolumn{7}{|l|}{ Earnings/Price } \\
\hline Average profit & $4.79 \%$ & $5.29 \%$ & $5.62 \%$ & $4.25 \%$ & $3.98 \%$ & $-0.81 \%$ \\
\hline Standard deviation & $9.43 \%$ & $9.75 \%$ & $8.47 \%$ & $8.53 \%$ & $8.89 \%$ & $7.07 \%$ \\
\hline Test $t$ & 6.0923 & 6.5023 & 7.9520 & 5.9854 & 5.3814 & -1.3625 \\
\hline p value & 0.0000 & 0.0000 & 0.0000 & 0.0000 & 0.0000 & 0.1730 \\
\hline \multicolumn{7}{|l|}{ Cashflow/Price } \\
\hline Average profit & $3.33 \%$ & $5.05 \%$ & $5.35 \%$ & $5.39 \%$ & $4.28 \%$ & $0.94 \%$ \\
\hline Standard deviation & $9.80 \%$ & $9.49 \%$ & $10.16 \%$ & $8.79 \%$ & $7.79 \%$ & $6.79 \%$ \\
\hline Test $t$ & 4.0840 & 6.3895 & 6.3226 & 7.3645 & 6.5859 & 1.6674 \\
\hline p value & 0.0000 & 0.0000 & 0.0000 & 0.0000 & 0.0000 & $0.0954^{* * *}$ \\
\hline \multicolumn{7}{|l|}{ Firm size } \\
\hline Average profit & $3.04 \%$ & $3.14 \%$ & $3.00 \%$ & $3.44 \%$ & $3.07 \%$ & $0.03 \%$ \\
\hline Standard deviation & $15.44 \%$ & $15.86 \%$ & $16.10 \%$ & $16.34 \%$ & $16.21 \%$ & $8.26 \%$ \\
\hline Test $t$ & 2.360 & 2.376 & 2.237 & 2.525 & 2.270 & 0.044 \\
\hline p value & 0.018 & 0.018 & 0.025 & 0.012 & 0.023 & 0.965 \\
\hline \multicolumn{7}{|l|}{ Leverage } \\
\hline Average profit & $5.08 \%$ & $4.68 \%$ & $4.96 \%$ & $5.14 \%$ & $4.49 \%$ & $-0.59 \%$ \\
\hline Standard deviation & $8.74 \%$ & $10.61 \%$ & $8.82 \%$ & $9.12 \%$ & $9.21 \%$ & $7.27 \%$ \\
\hline Test $t$ & 6.9738 & 5.2995 & 6.7489 & 6.7664 & 5.8509 & -0.9698 \\
\hline p value & 0.0000 & 0.0000 & 0.0000 & 0.0000 & 0.0000 & 0.3321 \\
\hline
\end{tabular}

Source: the authors.

* Significant at 1\%, *** Significant at 10\%. 
As for the E/P variable, we observe that, although average profits increase slightly between the lowest quintile (Q5) and the highest quintile (Q1) - resulting in a positive difference of $0,81 \%$ - , the result is statistically insignificant. Thus, we cannot conclude that value versus growth exists for portfolios based on the E/P index.

The third part of Table 3 presents results for the CF/P variable. Similarly to what was found for the $\mathrm{B} / \mathrm{M}$ index, profits of portfolios based on the CF/P index decrease almost monotonically between the top quintile and the bottom quintile, producing a $0.94 \%$ premium (Q1-Q5), significant at $10 \%$. This result contradicts what theory usually proposes, since, according to former evidence, high $\mathrm{CF} / \mathrm{P}$ ratio stocks presented better results than those with a low $\mathrm{CF} / \mathrm{P}$ ratio.

Regarding the firm size variable, no significant difference between the profits of value stocks (Q1) and growth stocks (Q5) was observed. Thus, the results of this phase of research do not indicate, a priori, the existence of the firm size effect documented by Banz (1981), in which stocks from smaller companies produce greater profits.

Finally, we observe that, although the leverage variable presents a small value premium, this result is insignificant. Thus, considering this first stage of analysis, we cannot confirm the existence of the leverage effect, proposed by Bhandari (1988), revealing a positive relationship between a company's capital structure and profits.

All this having been said, portfolio analysis offers evidence that value versus growth is not described in the Brazilian stock market, given that growth strategies are superior to value strategies. This result, however, is coherent with evidence presented by Mescolin, Braga and Costa Jr. (1997), Ramos, Picanço and Costa Jr. (2000), Pedreira (2005), Fregnani, Faneco and Famá (2008) and Saito, Savoia and Sousa (2009), in which growth stocks present greater profits than value stocks in some of the analyzed periods. It is important to note that this research uses a longer period than those hitherto carried out in Brazil, suggesting that value strategies can only achieve better results in the short term.

\subsection{Regression analysis}

This section presents results from univariate and multivariate regressions, whose goal is to identify the variables that best explain Brazilian stock profits in the period surveyed. All regressions were estimated using panel data.

For each specified model, we calculated the " $t$ " - for Student - test, in order to verify individual significance; and the "F" test, to analyze the joint significance of variables investigated. Tests were also made to verify the model's assumptions, such as the modified Wald test, so as to test homoscedasticity, and the Wooldridge test of Lagrange Multipliers, for autocorrelation in panel data. In cases where heteroscedasticity and/or autocorrelation were detected, we used the Huber-White robust variance-covariance matrix. After estimating with fixed and random effects, the Hausman test (1978) was carried out, in order to ascertain which model was most appropriate in each case.

\subsection{Univariate regressions}

Univariate regressions aim at analyzing the individual explanatory power of research variables. Their results are presented in Table 4. All variables, except the $\mathrm{E} / \mathrm{P}$ ratio, are significant at $1 \%$.

The $\mathrm{B} / \mathrm{M}$ ratio presents a $-0,216$ negative, significant coefficient. This result contradicts what is usually found in theory, which predicts that $\mathrm{B} / \mathrm{M}$ is positively connected to profits. This finding, however, is coherent with results from portfolio analysis (Table 3), which favor investment strategies for growth stocks. 
Confirming what was presented in Table 2 , the $\mathbf{E} / \mathbf{P}$ index is statistically insignificant to explaining profits. The dummy variable was also analyzed, in which " 0 " represents the negative values and " 1 " the positive values of the $\mathrm{E} / \mathrm{P}$ index. According to Table 4, the coefficient for this variable was positive and significant, suggesting that there is a difference when considering positive and negative earnings separately, confirming Gharghori, Stryjkowski and Veeraraghavan (2012).

Table 4 - Univariate regressions from profits for fundamental variables.

\begin{tabular}{l|c|c|c|c|c|c|c}
\hline & Constant & Coefficient & Adjusted R & F Test & Wald & LM & \\
\hline $\mathrm{B} / \mathrm{M}$ & $0.564^{*}$ & $-0.216^{*}$ & 0.1432 & $78.01^{*}$ & $590.50^{*}$ & $6.407^{*}$ & $55.55^{*}$ \\
\hline $\mathrm{E} / \mathrm{P}$ & $0.258^{*}$ & 0.0002 & 0.0004 & 0.23 & $500.48^{*}$ & 1.154 & 0.30 \\
\hline $\mathrm{DUMMY}$ & -0.026 & $0.319^{*}$ & 0.0378 & $13.36^{*}$ & $455.16^{*}$ & 1.065 & 0.03 \\
\hline $\mathrm{CF} / \mathrm{P}$ & $0.317^{*}$ & $-0.410^{* *}$ & 0.0177 & $4.84^{* *}$ & $318.28^{*}$ & 0.003 & $3.91^{* *}$ \\
\hline $\mathrm{VM}$ & $-2.082^{*}$ & 0.163 & 0.0274 & $68.13^{*}$ & $449.90^{*}$ & $4.845^{* *}$ & $50.44^{*}$ \\
\hline PO/AT & $0.237^{*}$ & 0.0004 & 0.0006 & 0.18 & $670.66^{*}$ & 1.345 & 0.10 \\
\hline
\end{tabular}

Source: the authors.

* Significant at 1\%, ** Significant at 5\%, *** Significant at 10\%.

Standard errors estimated with correction for heteroscedasticity and serial correlation, using the Huber-White robust matrix.

The CF/P variable presents a $-0,410$ negative, significant coefficient. This result also contradicts what is commonly found in theory, which states that the $\mathrm{CF} / \mathrm{P}$ index is positively connected to profits. This finding, however, is coherent with results from portfolio analysis (Table 3), which reveal that investment strategies for growth stocks achieve greater profits than those for value stocks.

With respect to variable VM, a 0,163 positive, significant coefficient can be observed. This result is inconsistent with the firm size effect documented by Banz (1981), in which the lower the company's market value, the greater the profits. This finding, however, is coherent with previous research carried out in the Brazilian market, such as Rodrigues (2000), Braga and Leal (2002) and Machado and Medeiros (2011), whose results indicate a favorable firm size effect for companies with high market values.

The PO/AT variable achieved a 0.0004 positive coefficient. Although the result is consistent with Bhandari's leverage effect (1988), it has no statistical significance. Mellone Jr. (1999) observed that leverage has no relevance to explaining Brazilian stock profits.

Considering results from univariate regressions, we can conclude, a priori, that the variables that best explain average profits are the $\mathrm{B} / \mathrm{M}$ and $\mathrm{CF} / \mathrm{P}$ ratios, although they presented a contrary relationship to what was expected. The fact that $\mathrm{B} / \mathrm{M}$ and $\mathrm{CF} / \mathrm{P}$ ratios presented reverse relationships seems to be, however, a specific feature of the Brazilian market, coherent with the results of Machado and Medeiros (2011), who observed a firm size effect that favored large companies, as well as that the $\mathrm{B} / \mathrm{M}$ ratio of portfolios made up of high market value stocks was smaller than the $\mathrm{B} / \mathrm{M}$ ratio of portfolios made up of low market value stocks - thus concluding that, in Brazil, growth opportunities were concentrated in high market value companies, similar results to this paper's.

High market value companies' greater profits, coupled with the fact that these companies have lower $\mathrm{B} / \mathrm{M}$ ratios, may lead, therefore, to the 
predominance of the growth strategy in Brazil. Additionally, we highlight the long period of research, which may signal the predominance of growth strategies in the long term. Periods over 12 months are considered long-term (CPC, 2011). Moreover, this research highlights the high volatility of capital markets in emerging countries, as revealed by Fama and French (1998).

Additional empirical evidence supports the findings of this research. Fama and French (1998) argue that value versus growth is a global phenomenon, but there are some exceptions. In Italy, growth stocks outperformed value stocks for portfolios based on book-to-market, earnings/ price and dividend/price variables. Considering this last variable only, there are two more exceptions: Germany and Singapore.

\subsubsection{Multivariate regressions}

Multivariate regressions aim at analyzing which fundamental variables best identify value and growth companies, following control for firm size and leverage. Their results are presented in Table 5.

Model A in Table 5 reveals that, when $\mathrm{B} / \mathrm{M}$ and $\mathrm{E} / \mathrm{P}$ ratios are simultaneously regressed, the $\mathrm{B} / \mathrm{M}$ ratio presents a negative and significant coefficient and the $\mathrm{E} / \mathrm{P}$ ratio a positive - but insignificant - coefficient. The $\mathrm{B} / \mathrm{M}$ ratio continues to present significant and negative coefficients in all other combinations of explanatory variables (models B, D, E, H, I and K), confirming results from Portfolio Analysis (Table 3) and univariate regression (Table 4).

Table 5 - Multivariate regressions from profits for fundamental variables.

\begin{tabular}{|c|c|c|c|c|c|c|c|c|c|c|c|}
\hline Models & Constant & $\mathbf{B} / \mathbf{M}$ & $\mathbf{E} / \mathbf{P}$ & CF/P & VM & PO/AT & $\begin{array}{l}\text { Adjusted } \\
\qquad \mathbf{R}^{2}\end{array}$ & F Test & Wald & $\mathbf{L M}$ & Hausman \\
\hline (A) $\mathrm{B} / \mathrm{M}, \mathrm{E} / \mathrm{P}$ & $0.562^{*}$ & $-0.215^{*}$ & 0.0001 & & & & 0.1432 & $39.99^{*}$ & $595.18^{*}$ & $6.48^{* *}$ & $56.41^{*}$ \\
\hline (B) $\mathrm{B} / \mathrm{M}, \mathrm{CF} / \mathrm{P}$ & $0.581^{*}$ & $-0.236^{*}$ & & -0.185 & & & 0.1830 & $27.11^{*}$ & $1.8 \mathrm{e}+28^{*}$ & $4.09^{* *}$ & $28.68^{*}$ \\
\hline (C) E/P, CF/P & $0.311^{*}$ & & 0.0004 & $-0.407^{* *}$ & & & 0.0175 & $4.68^{* *}$ & $328.32^{*}$ & 0.17 & $5.19^{* * *}$ \\
\hline (D) $\mathrm{B} / \mathrm{M}, \mathrm{E} / \mathrm{P}, \mathrm{CF} / \mathrm{P}$ & $0.579 *$ & $-0.236^{*}$ & 0.0002 & -0.184 & & & 0.1828 & $18.13^{*}$ & $359.01^{*}$ & $4.36^{* *}$ & $30.76^{*}$ \\
\hline (E) B/M, VM, PO/AT & $1.047^{* * *}$ & $-0.249^{*}$ & & & -0.031 & 0.00007 & 0.1498 & $17.09^{*}$ & $628.86^{*}$ & $4.94^{* *}$ & $33.95^{*}$ \\
\hline (F) L/P, VM, PO/AT & $-2.086^{*}$ & & 0.0001 & & $0.159^{*}$ & 0.00006 & 0.0266 & $18.39^{*}$ & $694.08^{*}$ & 2.37 & $35.21^{*}$ \\
\hline (G) CF/P, VM, PO/AT & $-2.312^{*}$ & & & $-0.294^{* * *}$ & $0.173^{*}$ & 0.0013 & 0.0617 & $25.39^{*}$ & $389.14^{*}$ & 2.08 & $29.93^{*}$ \\
\hline (H) B/M, E/P, VM, PO/AT & $1.048^{* * *}$ & $-0.249^{*}$ & 0.0002 & & -0.031 & 0.00007 & 0.1497 & $12.98^{*}$ & $637.89^{*}$ & $5.02^{* *}$ & $34.64^{*}$ \\
\hline (I) $\mathrm{B} / \mathrm{M}, \mathrm{CF} / \mathrm{P}, \mathrm{VM}, \mathrm{PO} / \mathrm{AT}$ & 0.867 & $-0.259^{*}$ & & -0.192 & -0.019 & 0.00005 & 0.1783 & $16.96^{*}$ & $304.12^{*}$ & $3.08^{* * *}$ & $34.03^{*}$ \\
\hline (J) E/P, CF/P, VM, PO/AT & $-2.311^{*}$ & & 0.0003 & -0.291 & $0.173^{*}$ & 0.0015 & 0.0618 & $19.10^{*}$ & $399.57^{*}$ & 2.38 & $31.46^{*}$ \\
\hline $\begin{array}{l}\text { (K) B/M, E/P, CF/P, VM, } \\
\mathrm{PO} / \mathrm{AT}\end{array}$ & 0.866 & $-0.259^{*}$ & 0.0003 & -0.189 & -0.019 & 0.0005 & 0.1781 & $14.26^{*}$ & $313.33^{*}$ & $4.73^{* *}$ & $36.06^{*}$ \\
\hline
\end{tabular}

Source: the authors.

* Significant at $1 \%,{ }^{* *}$ Significant at 5\%, *** Significant at $10 \%$.

Standard errors estimated with correction for heteroscedasticity and serial correlation, using the Huber-White robust matrix. Absence of multicollinearity, with tolerance values varying between 0,732 and 0,936 and FIV varying between 1,068 and 1,367 .

With respect to the E/P index, positive coefficients - but insignificant for all other models - can still be observed. Thus, when regressed along with $\mathrm{B} / \mathrm{M}, \mathrm{FC} / \mathrm{P}$ and control variables $\mathrm{VM}$ and
$\mathrm{PO} / \mathrm{AT}$, the E/P index then presents a similar result to that obtained by univariate regression (Table 4) - that is, no relevance to explaining analyzed stock profits. 
Model B shows joint regression results for $\mathrm{B} / \mathrm{M}$ and $\mathrm{CF} / \mathrm{P}$ indexes. Both variables present negative coefficients, confirming results from univariate regressions (Table 4). Only the B/M index was statistically relevant, however. The $\mathrm{CF} / \mathrm{P}$ index presented negative coefficients for all the other regressions, but was only significant when combined with the E/P index and with control variables (models $\mathrm{C}$ and $\mathrm{G}$ ). In all models in which it was combined with $\mathrm{B} / \mathrm{M}, \mathrm{FC} / \mathrm{P}$ was insignificant, which may indicate that its explanatory power of stock profits is incorporated by the $\mathrm{B} / \mathrm{M}$ index.

According to Table 5, amongst proxies used to measure growth-value strategies, therefore, the book-to-market index proved to be consistent, since, in all models, it presented the same sign (negative, confirming findings from Table 4) and statistical significance. The $\mathrm{E} / \mathrm{P}$ variable was not significant for any model, confirming results from univariate regression and proving irrelevant to explaining profits. The $\mathrm{CF} / \mathrm{P}$ index, although it was statistically significant in univariate regression, was no longer significant when combined with the $\mathrm{B} / \mathrm{M}$ index. This result may indicate that its explanatory power is incorporated by the $\mathrm{B} / \mathrm{M}$ index.

With regard to control variables, for the VM variable results of multivariate regressions are inconclusive, since it presented a significant and positive coefficient in models only (F, G and $J)$. Although this result confirms what portfolio analysis found, when combined with the $\mathrm{B} / \mathrm{M}$ index the firm size variable presented a negative, insignificant coefficient. Thus, the existence of the firm size effect documented by Banz (1981) is not proven in the Brazilian market. For the $\mathrm{PO} / \mathrm{AT}$ variable, coefficients were positive in all models, but were statistically insignificant. Thus, in this research, it is not possible to confirm the existence of Bhandari's leverage effect (1988) in the Brazilian market.

All this having been said, we can conclude that the $\mathrm{B} / \mathrm{M}$ index is the best proxy for identifying value and growth companies in Brazil. This result is coherent with the findings of Gharghori, Stryjkowski and Veeraraghavan (2012) and contradicts the results of Barbee, Mukherji and Raines (1996). Moreover, it confirms the results of almost all Brazilian research that included this variable.

\section{CONCLUSION}

This research aimed at analyzing the existence of value versus growth in the Brazilian stock market in the 1995-2008 period, and at identifying the variable that best explains its impact on stock profits. Results from portfolio analysis favor growth strategies, given that growth stocks achieved greater profits than value stocks in portfolios based on book-to-market and cashflow/ price variables. Results were not statistically significant for the other variables. Results from regression analysis confirm what was found in portfolio analysis, confirming the importance of $\mathrm{B} / \mathrm{M}$ to explaining Brazilian stock profits.

Although most Brazilian studies consider value strategies to be superior to growth strategies, many of them also present results that favor growth strategies in certain periods. It is important to note that this research covers a period of thirteen years of analysis, longer than other studies carried out in Brazil. Thus, we believe that, to date, value strategies performed better because they are concentrated in the short term. In the long term, there is evidence that results favor growth strategies. According to the Accounting Pronouncements Committee - CPC (2011) (Comitê de Pronunciamentos Contábeis - CPC), in this paper a period shorter than 12 months is considered short-term, and a period over 12 months is considered long-term. Additionally, we emphasize the high volatility of the Brazilian capital market. Results in this paper are similar to those obtained by Fama and French (1998) in Italy, Germany and Singapore.

In this research, we used firm size and leverage as control variables, considering its 
documented connections with profits. However, results do not confirm that these effects do in fact exist in the Brazilian market. Contrary to expectations, we found a negative relationship between the leverage variable and stock profits in portfolio analysis. In univariate and multivariate regressions, although the variable presented a positive relationship with profits, as predicted by theory, there was no statistical significance. Regarding the firm size effect, portfolio analysis observed the firm size effect in favor of large companies, similarly to results from Rodrigues (2000), Braga and Leal (2002) and Machado and Medeiros (2011). In regressions, results were inconclusive.

This particular Brazilian market trend justifies the fact that the book-to-market and the cashflow/price ratios are reversed in this research and, in turn, supports the absence of a premium in favor of value stocks and the presence of investment strategies with growth stocks. Moreover, we conclude that, to obtain greater profits with this type of strategy, the variable that best identifies growth stocks is the book-to-market index.

Finally, we suggested that further research carry out analysis in short periods, in order to verify whether value and growth strategies are indeed short or long-term phenomena. Furthermore, we suggest other proxies are tested, such as the price/sales index and the dividend yield.

\section{REFERENCES}

ARELLANO, M.; BOVER, O. La econometria de datos de painel. Investigaciones Económicas, México, v. 19, n. 1, p. 3-45, enero 1990.

ATHANASSAKOS, G. Value versus growth stock profits and the value premium: the Canadian experience 1985-2005. Canadian Journal of Administrative Sciences, Chichester, v. 26, n. 2, p. 109-121, June 2009.
BANZ, R. The relationship between profit and market value of common stocks. Journal of Financial Economics, Amsterdam, v. 9, n. 1, p. 3-18, Mar. 1981.

BARBEE, W. C.; MUKHERJI, S.; RAINES, G. Do sales-price and debt-equity explain stock profits better than book-market and firm size? Financial Analysts Journal, Charlottesville, v. 52, n. 2, p. 56-60, Mar./Apr. 1996.

BHANDARI, L. C. Debt/equity ratio and expected common stock profits: empirical evidence. Journal of Finance, Malden, v. 43, n. 2, p. $507-$ 28, June 1988.

BLACK, F. Capital market equilibrium with restricted borrowing. The Journal of Business, Chicago, v. 45, n. 3, p. 444-455, July 1972.

; JENSEN, M. C.; SCHOLES, M. The capital asset pricing model: some empirical tests. In: JENSEN, M. C. Studies in the theory of capital markets. New York: Praeger, 1973. p. 79-121.

BLUME, M. E. Betas and their regression tendencies. Journal of Finance, Malden, v. 30, n. 3, p. 785-795, June 1975.

BRAGA, C. M.; LEAL, R. P. C. Ações de valor e de crescimento nos anos 1990. In: BONONO, $M$. Finanças aplicadas ao Brasil. Rio de Janeiro: FGV Ed., 2002. p. 235-248.

CAI, J. Glamour and value strategies on the Tokyo stock exchange. Journal of Business Finance \& Accounting, Oxford, v. 24, n. 9, p. 1291-1310, Oct./Dec. 1997.

CAPAUL, C.; ROWLEY, I.; SHARPE, W. F. International value and growth stock profits. Financial Analysts Journal, Charlottesville, v. 49, n. 1, p. 27-36, Jan./Feb. 1993.

CHAN, L.K.; HAMAO, Y.; LAKONISHOK, J. Fundamentals and stock profits in Japan. Journal of Finance, Malden, v. 46, n. 5, p. 1739-1789, Dec. 1991. 
COMITÊ DE PRONUNCIAMENTOS CONTÁBEIS - CPC. Pronunciamento Técnico CPC 26 (R1): apresentação das demonstraçôes contábeis. Brasília, 2011. Available at: < http:// www.cpc.org.br/pdf/CPC26_R1.pdf>.Accessed: December 1, 2012.

COPELAND, T. E.; WESTON, J. F.; SHASTRI, $K$. Financial theory and corporate policy. 4th ed. Reading, MA: Pearson Addison Wesley, 2005.

COSTA JR., N.; NEVES, M. Variáveis fundamentalistas e retornos das açōes. In: COSTA JR., N.; LEAL, R.; LEMGRUBER, E. Mercado de capitais: análise empírica no Brasil. São Paulo: Atlas, 2000. p. 99-111.

CUPERTINO, C. M.; COELHO, R. A. Alavancagem, liquidez, tamanho, risco, imobilizado e intangíveis: um estudo de algumas condicionantes do book-to-market em empresas brasileiras. In: CONGRESSO USP DE CONTROLADORIA E CONTABILIDADE, 6., 2006, São Paulo. Anais... São Paulo: FEA-USP, 2006.

DANIEL, K.; TITMAN, S. Evidence on the characteristics of cross sectional variation in stock profits. Journal of Finance, Malden, v. 52, n. 1, p. 1-33, Mar. 1997.

FAMA, E. F. Efficient capital markets: a review of theory and empirical work. Journal of Finance, Malden, v. 25, n. 2, p. 383-417, May 1970.

; FRENCH, K. R. The cross-section of expected stock profits. Journal of Finance, Malden, v. 47, n. 2, p. 427-465, June 1992.

; Common risk factors in the profits on stocks and bonds. Journal of Financial Economics, Amsterdam, v. 33, n. 1, p. 3-56, Feb. 1993.

Size and book-to-market factors in earnings and profits. Journal of Finance, Malden, v. 50, n. 1, p. 131-155, Mar. 1995.
. Multifactor explanations of asset price anomalies. Journal of Finance, Malden, v. 51, n. 1, p. 55-84, Mar. 1996.

. Value versus growth: the international evidence. Journal of Finance, Malden, v. 53, n. 6, p. 1975-1999, Dec. 1998.

The capital asset pricing model: theory and evidence. Journal of Economic Perspectives, Nashville, v. 18, n. 3, p. 25-46, Summer 2004.

The value premium and the CAPM. Journal of Finance, Malden, v. 61, n. 5, p. 2163-2185, Oct. 2006.

FRALETTI, P. B. Ensaio sobre a taxa de juros em reais e sua aplicaçáo na análise financeira. 2004. 160 f. Tese (Doutorado em Administração) - Universidade de São Paulo, São Paulo, 2004.

FREGNANI, C. A.; FANECO, R. M.; FAMÁ, R. Avaliação do desempenho, em termos de risco e retorno, das açóes value e growth no mercado acionário brasileiro no período pós-inflacionário, de 1995 a 2005. In: SEMEAD - SEMINÁRIOS EM ADMINISTRAÇÃO: EMPREENDEDORISMO EM ORGANIZAÇÔES, 11., 2008, São Paulo Anais... São Paulo: FEA-USP, 2008.

GHARGHORI, P.; STRYJKOWSKI, S.; VEERARAGHAVAN, M. Value versus growth: australian evidence. Accounting \& Finance, Carlton, 2012. In press. Available at: <http://onlinelibrary.wiley. com/doi/10.1111/j.1467-629X.2012.00474.x/ abstract>. Accessed: November 12, 2012.

HAUGEN, R. A. The new finance: the case against efficient markets. Englewood Cliffs: Prentice Hall, 1995.

HAUSMAN, J. A. Specification tests in econometrics. Econometrica, Oxford, v. 46, n. 6, p. 1251-1271, Nov. 1978.

LA PORTA, R. et al. Good news for value stocks: further evidence on market efficiency. Journal of Finance, Malden, v. 52, n. 2, p. 859-874, June 1997. 
LAKONISHOK, J.; SHLEIFER, A.; VISHNY, R.W. Contrarian investment, extrapolation and risk. Journal of Finance, Malden, v. 49, n. 5, p. 1541-1578, Dec. 1994.

LELEDAKIS, G.; DAVIDSON, I. Are two factors enough? The UK evidence. Financial Analysts Journal, Charlottesville, v. 57, n. 6, p. 96-105, Nov./Dec. 2001.

LINTNER, J. The valuation of risk assets and the selection of risky investments in stock portfolios and capital budgets. Review of Economics and Statistics, Cambridge, v. 47, p. 13-37, Feb. 1965.

LO, A. W. Efficient Markets Hypothesis. Working Paper, MIT Sloan School of Management, 2007. Available at: <http://papers.ssrn.com/sol3/papers. cfm?abstract_id=991509>. Accessed: November $12,2012$.

LOUGHRAN, R. Book-to-market across firm size, exchange and seasonality: is there an effect? Journal of Financial and Quantitative Analysis, Seattle, v. 32, n. 3, p. 249-268, Sept. 1997.

MACHADO, M. A.V.; MEDEIROS, O. R. Modelos de precificação de ativos e o efeito liquidez: evidências empíricas no mercado acionário brasileiro. Revista Brasileira de Finanças, Rio de Janeiro, v. 9, n. 3, p. 383-412, 2011.

MELLONE JR., G. Evidências empíricas da relação cross-section entre retorno e earnings to price ratio e book to market ratio no mercado de açôes no Brasil no período de 1995 a 1998. In: ENCONTRO NACIONAL DOS PROGRAMAS DE PÓS-GRADUAÇÃO EM ADMINISTRAÇÃO, 23., 1999, Foz do Iguaçu - PR. Anais... Foz do Iguaçu: ANPAD, 1999.

MESCOLIN, A.; BRAGA, C.; COSTA JR., N. Risco e retorno das value e growth stocks no mercado de capitais brasileiro. In: ENCONTRO NACIONAL DOS PROGRAMAS DE PÓS-GRADUAÇÃO EM ADMINISTRAÇÃO, 21., 1997, Rio das Pedras - RJ. Anais... Rio das Pedras: ANPAD, 1997.
PEDREIRA, E. B. Retornos e riscos das açóes de valor e de crescimento no mercado brasileiro no período de janeiro de 2001 a junho de 2004, com base no IBrX50. In: CONGRESSO USP DE CONTROLADORIA E CONTABILIDADE, 5., 2005, . Anais... São Paulo: FEA-USP, 2005.

RAMOS, P.; PICANÇO, M.; COSTA JR., N. Retornos e riscos das value e growth stocks no mercado brasileiro. In: COSTA JR., N.; LEAL, R.; LEMGRUBER, E. Mercado de capitais: análise empírica no Brasil. São Paulo: Atlas, 2000. p. 124-138.

RODRIGUES, M. O efeito valor, o efeito tamanho, e o modelo multifatorial: evidências do caso brasileiro. In: ENCONTRO NACIONAL DOS PROGRAMAS DE PÓS-GRADUAÇĀO EM ADMINISTRAÇÃO, 24., 2000, Florianópolis SC. Anais... Florianópolis: ANPAD, 2000.

ROSS, S. The arbitrage theory of capital asset pricing. Journal of Economic Theory, San Diego, v. 13, n. 3, p. 341-360, Dec. 1976.

ROSTAGNO, L.; SOARES, R. O.; SOARES, K. T. C. Estratégias de valor no mercado acionário brasileiro. Revista Eletrônica de Administraçáo da UFRGS - REad, Porto Alegre, ed. 48, v. 11, n. 6, nov./dez. 2005.

Estratégia de valor e de crescimento em ações na Bovespa: uma análise de sete indicadores relacionados ao risco. Revista de Contabilidade e Finanças da USP, São Paulo, v. 42, p. 7-21, set./dez. 2006.

SAITO, A. T.; SAVOIA, J. R. F.; SOUSA, A. F. Estratégias de valor e crescimento e a avaliação de empresas no setor elétrico no Brasil. In: SEMEAD - SEMINÁRIOS EM ADMINISTRAÇĀO: EMPREENDEDORISMO EM ORGANIZAÇÕES, 12., 2009, São Paulo. Anais... São Paulo: FEA-USP, 2009.

SÁNCHEZ GAMBOA, S. A. Epistemologia da pesquisa em educaçáo.1987. 240 f. Tese 
(Doutorado em Educação) - Universidade Estadual de Campinas, Campinas-SP, 1987.

SHARPE, W. F. Capital asset prices: a theory of market equilibrium under conditions of risk. Journal of Finance, Malden, v. 19, n. 3, p. 425442, Sept. 1964.
WOOLDRIDGE, J. M. Econometrics analysis of cross section and panel data. Cambridge: MIT Press, 2002.

ZHANG, C. On the explanatory power of firm-specific variables in cross-sections of expected profits. Journal of Empirical Finance, Amsterdam, v. 16, n. 2, p. 306-317, Mar. 2009. 